\title{
The role of identity for regional actors and citizens in a splintered region: The case of Päijät-Häme, Finland
}

\author{
JONI VAINIKKA
}

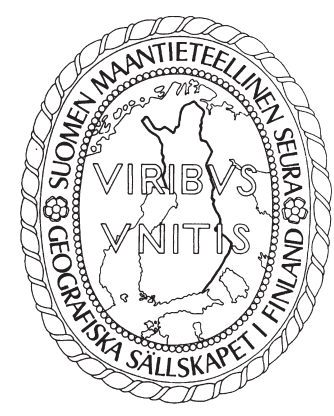

Vainikka, Joni (2013). The role of identity for regional actors and citizens in a splintered region: The case of Päijät-Häme, Finland. Fennia 191: 1, pp. 25-39. ISSN 1798-5617.

Regions are often understood as social and discursive constructs that are perpetually at the heart of the politics of spatial distinctions. Although regions transform over time, they are used in collective discourses as ways of structuring space and they can become important elements for individual identity narratives and practices. The proponents of the competitiveness rhetoric increasingly utilize the ideas of social capital and trust positing that regions are knowingly responsible for their affluence and economic growth. In Finland, various institutional agents have operationalized provincial spaces as imperative policy instruments. At the same time, their meaning has remained rather ambiguous to their citizens, whose spatial identifications can be eclectic and reflexive. This article focuses on one particular region, Päijät-Häme in southern Finland to uncover why the supposed internal cohesion does not seem to manifest at the provincial level. The paper approaches regional identity from two angles. First, it scrutinizes how regional actors conceptualize the region and how they facilitate regional identity discourses, and second, it analyses how individuals construct their spatial identities and belonging and studies the meaning of the institutionalized region in this process. The empirical material consists of eleven interviews with institutional actors representing regional policy, trade, education and media and four focus group interviews with locally- or universally-orientated social movements representing the general public. In this article, I argue that historical fractures and differently aligned spatial strategies can hinder attempts to reconfigure regional identities, and by implication, development discourses. I also indicate that while the province does not necessarily provide compelling identity materials, the need to belong has not disappeared in the currents of globalization.

Keywords: Päijät-Häme, regional identity, focus groups, region-building, regional actors, social movements

Joni Vainikka, Department of Geography, University of Oulu, PO Box 3000, FI90014 University of Oulu, Finland, email: joni.vainikka@oulu.fi

\section{Introduction}

Regions are often understood as social and discursive constructs that are perpetually at the heart of politics of spatial distinctions. Their meanings are mediated by time in an evolutionary fashion that is echoed in an observation from Henri Bergson (1911: 2), 'We change without ceasing'. Regions can become natural and mundane parts of people's spatial identities. They provide ways to 'read' space or act as subconscious reference points for self-esteem, belonging and distinctiveness (de Cillia et al. 1999; Agnew 2001; Savage et al. 2005; Donaldson 2006; Antonsich 2010). The transformation of collective regional identity discourses is a lingering process. The ways citizens value regionalism, are affected by regional emblems and picture its territory cannot be changed overnight. The residues of past cultural practices and meanings persist as long as people believe in and make claims on them (Paasi 2002a). 
Regions have in recent years become, depending on the viewpoint, either pawns or key players in neoliberal political struggles. Regions are the instruments of either devolution or integration policies or commodified images supporting the competitiveness rhetoric (Brenner 2004; Jones \& MacLeod 2004; Moisio 2007; Bristow 2010). It has also become more popular to state that regional practices stretch in space so that their representations and influence can be read well outside their territories (Allen et al. 1998), or to conceptualize regions as both bounded and porous (Morgan 2007), a networked space in itself (Prytherch 2010). The growing interconnectedness between the archipelago of economic stepping-stones (Petrella 2000) and the mounting relational redefinition and liquidity of spatial identities (Bauman 2004; Massey 2005) seem to debase the often 'sedentarist' identity discourses that could be able to anchor social cohesion (Tomaney 2007). It is therefore a challenge to understand and explore, as Benno Werlen (2009) notes, the many ways places and spatial entities are made meaningful. Understanding this everyday 'geography-making', where regions are not fixed, pre-existing entities but rather 'thought-and-practiced' social constructs of actual people (see also Jonas 2012) can legitimate the direction of institutional regionbuilding.

My primary contribution is to bring together the role and operationalization of identity in institutional settings and the contextual ways individuals apply regions in their identity narratives. This article contributes to the ongoing discussion that seeks, first, a more definitive conceptualization of how and why regional identities become meaningful to citizens (Savage et al. 2005; Antonsich 2010; Vainikka 2012), and, second, to what extent governance discourses and regional advocates (can) draw from and discursively sustain such identities (Lanigan 2001; Frisvoll \& Rye 2009; Paasi 2013). Using the province of Päijät-Häme in southern Finland as a case study, this article follows the proposals made by Anssi Paasi (2009a) to 'combine the political-economic focus with questions of subjectification and identity formation' and by Anjet Schlottmann (2008: 827) to explore 'the elements and hidden logics of symbolic regionalization in detail'. Through problematizing the roles of regional identity, this article examines in what ways the region under examination actually 'exists' and how antecedent territorial structures and meanings influence on the contempo- rary institutionalized regional entity (Paasi 1986; Bialasiewicz 2002; Jones \& MacLeod 2004).

I approach this outline through following research questions: 1) How do various regional institutional actors conceptualize the region and facilitate regional identity discourses? 2) How do individuals construct their spatial identities and belonging and is the institutional region part of this process? These questions are scrutinized in relation to a contextual spatial vocabulary and regional formation. Päijät-Häme is characterized by comparably late institutionalization (cf. Paasi 1986) but also by migration, proximity to a dominant metropolitan area and a splintered regional structure as the central city of Lahti is surrounded by areas where the former county boundaries still matter. The province thus offers a fitting illustration how political struggles and societal change can transform regionality before collective identities and efforts to orchestrate them are shaped around it.

Following this introduction, the concepts of 'region' and 'regional identity' and the research materials and methodology are discussed in more detail. The third part contextualizes the case study region and reconstructs the historical traces that can inform regional imaginaries. The fourth part draws on eleven semi-structured interviews with regional actors in order to analyse the meanings associated with the spatial structure of the province, the efforts used in region-building, and the contemporary ways of facilitating regional identity. The fifth part gives voice to four locally- or universally-orientated social movements interviewed in focus groups to unravel the meanings of the province as part of an identity repertoire. In the discussion, I further consider why does the current emphasis on institutional regional identity often diverge from the thought-and-practiced attachments and identifications and what are the possible consequences of this cleavage for regional development practice.

\section{Conceptualizing regions and regional identities}

The region, as a 'floating signifier', can be conceptualized in multiple ways (Thrift 1990) and in different contexts (Paasi 2002b). Regions do not follow an automatic scalar logic of reproduction as various agencies asynchronously (re)construct 
them (Thrift 1983; Paasi 1986). Nevertheless, social, political or ethnic discourses can make regions appear as inherited cultural entities, especially if these regions have preceded or played an integral role in state formation (Johnson \& Coleman 2012). The endurance of regional entities is often dependent on the geohistorical circumstances from which they have emerged and on the presence and becoming of their territorial and symbolic shapes and their wider institutionalization to a regional system (Paasi 1986). However, the often nationally embedded socio-cultural construction of regions (Sayer 1989; MacLeod \& Jones 2001) has to some extent given way to more politicoeconomic - new regionalist - approaches (Brenner 2004; Jonas 2012).

The shift in regional politics from spatial Keynesianism to a more open policy that leans on relative competitiveness and hands the responsibility of the future over to the regions themselves, has changed the conceptualizations of the region. The neoliberal regional competitiveness rhetoric along with the advancement of global economic integration has reformed cities and regions into key media between the state and the market. This has created a new mosaic of economic performance and transformed the role of the state in strategic planning (Keating 2001; Brenner 2004; Bristow 2010; Terlouw 2012). The driving forces of regional competitiveness are reflected in the generative, innovative and dynamic workforce (Florida 1995), in economic networks of trust (Cooke \& Morgan 1999), in organized social capital (Putnam 1994), and in the place promotion created to convey the vibrancy of regions (Syssner 2009; Boisen et al. 2011). Employing a limited number of successful case regions around the world (Silicon Valley, Baden-Württenberg, Emilia-Romagna, etc.), the development-by-competition ideology has been constructed to harness presumed regional economic agendas without always questioning the presumptions that sustain actually existing regional communities (Paasi 2009b), or the roadmaps prepared to achieve such development (Sotarauta 2010). Gillian Bristow (2010) shows that regional actors are tempted into competitiveness talk where identity becomes a brand or a 'market-orientated identity' (Lanigan 2001). Using the region as a unilateral apparatus of political economy or imagining benchmarked policy practices and strategies by reconfiguring spatial structures can alienate regions from their socio-cultural meanings and, indeed, generate regions that conflict with broader historical spatial continuums, in which politicians have a hard time believing, let alone the citizens (Antonsich 2010, see also Deacon 2004 on SouthWest England and Zimmerbauer 2011 on certain Finnish sub-regions). There is, thus, a need for a grounded regional identity politics, where understanding regional actors' operational prerequisites is the starting point for mobilizing competitive ambitions.

Regions are not mere rhetoric mediums through which political status or economic competitiveness funnels through, for they possess symbolic, discursive power and can serve as expressive socio-spatial categories. Paasi (1986, 2002b) argues for a two-fold constitutive and conditioned understanding of region-related identities. He formulates an 'identity of a region' as an expression of power, where distinguishable or imagined features of nature, culture and inhabitants are used in selective discourses of distinction. Based on this institutionally operated discourse an ideal, performable and collective 'regional identity' can become crystallized as a part of a reflexive and symbolic meaning system. Such identity discourses are actively promoted and realigned by the political elite, the media and regional organizations through effectual maps, heritage, regional emblems, imageries and representations (Frisvoll \& Rye 2009; Syssner 2009; Paasi 2013). They are also performed in everyday life as a means to understand and structure space, as parts of spatial vocabularies and as mediums of belonging (Savage et al. 2005; Donaldson 2006; Vainikka 2012).

Drawing on the websites of Dutch and Northwest German regional administrations that concentrate on external audiences, Kees Terlouw (2012) argues that we are witnessing a time when 'traditional and historical rooted well-established regional identities' or 'thick' identities of formal regions become ever more blurred in an interrelated and changeable world; the 'thin' regional identities based on functional co-operation and competitiveness take over the meaning of regional identity. ${ }^{1}$ Martin Jones and Gordon MacLeod (2004: 435) make a parallel distinction between 'spaces of regionalism' and 'regional spaces' based on how regions are approached either in political and cultural debates or by economic geographers. The former framework of concepts reiterates claims to citizenship and civic identity, political mobilization and the cultural expression of regions. The latter is related to concepts such as 'institutional thickness' or 'regional innovations sys- 
tems' that enable successful quicksilver recipes for regional co-operation and persuade new functional ensembles. However, the ways in which the affective association with the region shines like a beacon for the political remaking of the competitive region or the connection between the 'thick' and the 'thin' is often elusive or passed over in silence. The strategic or political regional identities (van Houtum \& Lagendijk 2001; Paasi 2013) that rely on economically motivated cartographic representations and perceived future territorial conditions often contradict with both established power structures and inherited social and cultural regional representations (Syssner 2009). While new geostrategic constellations can be created and the legitimizing written identities transformed, the social and cultural identities that operate as learned categorization processes are hard to eradicate from public discourses.

\section{Methodological strategies}

Since regions are cumulative spatial processes holding sediments of past ascendancies and vernacular practices, it is important to interpret the development and transformations of the regional system and the region. Following the geohistorical contextualization of the comparably new administrative case region, Päijät-Häme, the qualitative textual analysis for institutional understandings that discursively operationalizes regional identity is based on individual interviews with key regional actors from regional institutions. The directors of regional administrative, economic and cultural bodies and the editors of the regional papers, for example, play a key role in framing the Finnish provinces and in creating regional images and identity discourses. ${ }^{2}$ Of the eleven people interviewed two were women and nine men, their average age was 54, and three participants had worked in their current position for under two years. Three of the thirty to sixty-minute interviews were conducted in November 2008 and eight in October 2009. ${ }^{3}$

It is equally important to get behind the institutional, often promotional talk and scrutinize the meaning of the region for ordinary people. Assuming that narratives of regional identities are socially and interpersonally constructed, the method for unravelling their meaning should optimally promote contextual social interaction (cf. Bosco \& Herman 2007). Peter Hopkins (2007: 529) states that focus groups are effective when studying 'people's everyday engagements with their social and spatial worlds'. This method is influential in generating shared knowledge and revealing tacit positions, opinions and feelings (Johnson 1996), and it has been used, for example, in comparative studies investigating perceptions of regions among students (Antonsich 2010) and to explore semi-public discourses relating to national identities (de Cillia et al. 1999).

In this study, the spatial and regional identity narratives produced by four social movement groups are analysed. These groups apply different scalar strategies and their focus of activities is typically on local or universal issues. The globally distributed Friends of the Earth and Amnesty International aspire for environmentally sustainable societies and work to protect human rights respectively. Two groups operating in the city of Lahti were selected to exemplify presumably more universal mindsets. The nationwide Youth Societies and Local Heritage Associations are spin-offs of the nineteenth century nation-building, advancing local identities, preserving heritage and enlivening folk customs. Contrary to the aforementioned, their local groups can, in practice, be found in every municipality. Groups based in Hollola and Sysmä municipalities were selected to represent presumably more particular and local spatial imaginaries. With this selection that included distinct and variegated social categories (cf. Gustafson 2001), it is possible to avoid some of the socially and politically biased assumptions of the province that would manifest if scrutinizing only certain cohorts or groups of people. If the province is a part of the lived and practiced spatialities of the members of these groups, it could be so for every other people involved in the spheres of civic life. Altogether, twenty-one people, fourteen men and seven women, participated in four focus groups in November 2008. Their average age was 54, five of them were under 40, ten between 40 and 63 and six over the official Finnish retirement age of 63. In comparison to the general public, specialist occupations are over-represented.

The qualitative textual analysis of the two sets of interviews sought to capture the shared visions of identity and the region but also the various discursive meanings (Barbour 2005) regional identity holds for actors in regionally based organizations and for different citizens. The analysis that follows is based on my close reading of the transcribed material, preliminary coding and the conceptual 
categories that I formulated from the recurrent themes and ideas in the material (Tuffin \& Howard 2001; Warren \& Karner 2010).

\section{The formation of Päijät-Häme}

Päijät-Häme is a province, maakunta ${ }^{4}$, and a federation of eleven municipalities formed around the 102,000-inhabitant city of Lahti. The name Päijät-Häme - a compound of a dialectical form of Lake Päijänne and of the primordial community of Häme - is an invention of the 1930s which increased in popularity in the 1950s when the Lahti-centred region strengthened as an economic-functional entity. The city, comprising half of the population of the region, however, provides a widely used parallel term 'Lahti region' (cf. Kallio et al. 2010).

The legitimation of regional projects and their institutionalization often relies on historiographies that extend the contemporary regional frame longitudinally to find purchase for the current social discourses (Paasi 1986; Bialasiewicz 2002; Jones \& MacLeod 2004). Jouko Heinonen (1997) reconstructed the initial formation of Päijät-Häme around the fourteenth century Greater Hollola hundred and deanery, which, as one-third of Häme, had presumably been the last subject of a mediaeval struggle between Eastern and Western realms and ecclesiastical powers before Häme (Tavastia) was gradually subjugated under Swedish Catholic rule and taxation (Kerkkonen 1962; Taavitsainen 1990). While this historical discourse takes notes from an archived, documented memory (Ricœur 2000) and presumes the coherence of the archaic Hollola, the current territory is more a palimpsest space where some demarcations are erased and overwritten while others coexist as scripts of different social legacies (cf. Schein 1997: 662; Vainikka 2012).

The current regional frame was part of the Tavastia or Tavastia-Nylandia counties, lääni, until $1748 .{ }^{5}$ The eastern boundary of the county shifted twice to the west, first, as a ramification of the Treaty of Åbo and, second, as a search for 'natural boundaries', before the Russian administrators, in 1831, redrew county boundaries to fit the functionality and the needs of early nineteenth century society. This endowed PäijätHäme with an administratively splintered history separated into the counties of Tavastehus,
Nyland and St. Michel until the 1990s (see Fig. 1). Nevertheless, the intensification of regional identity discourses is often related to the outset of nationalism (Hobsbawm 1983; Paasi 2013). Based on earlier academic depictions, nine provinces were canonized in the nineteenth century as the stereotypical and prevailing identity regions. The couriers of this form of provincialism were mass communication, the student nations at Helsinki University who vaguely imitated the fourteenth century castle dominions or sixteenth century duchies and earldoms (Jutikkala 1949) and the school book Boken om Wårt Land that from 1875 taught pupils national and regional characteristics (Topelius 1879). This patriotic regionalist ideology, coupled with the emergence of several social movements striving to enlighten and regionalize cultural life, resulted in the gradual formation of Provincial Federations, makkuntaliitto, sometimes rearranging irrespective of the established regional entities or the later retitled 'historical' provinces from 1927 onwards (Häkli 1998).

Instead of deriving from the restructurings of state spaces, imagined regional or vernacular communities or even civil society institutions, Päijät-Häme is a child of logistics. The railway routing of the Helsinki-St. Petersburg line in 1870 through a small hamlet of Hollola's Lahti, which was equipped with an inland harbour for steamships that were able to operate throughout the entire Päijänne water system, eventually created a new economic centre. The subsequent industrialization and growth compelled city rights to be given to Lahti in 1905, without state potentates ever promoting its foundation (Heinonen 1997). Although proposals for Lahticentred regions were made from the 1920s onwards, only after a Regional Planning Authority was appointed to Päijät-Häme in 1967 (SuurHollola 1968) did the province gather more favourable attitudes towards a Provincial Federation - the last to be established. Framed in the restrictive division of three counties, the city of Lahti grew at such a pace, spurred on by the post-war resettlement of Karelians, that attention had to be focused on the development of the city more than on the cultural distinctiveness of the emerging economic-functional region. The Provincial Federation as a cultural institution had some impact on the construction of regional symbolism and awareness but as late 
as in the 1980s, people had to be 'educated' on the existence of Päijät-Häme (Kuikka 1985).

The Regional Development Act of 1994 merged the Provincial Federations and the Regional Planning Authorities into nineteen Regional Councils, makkunnan liitto. The motivation to reconstitute culturally and functionally meaningful regions developed from Finland's intention to join the European Union and from the shift to a program-based regional policy. Now the provinces, as local government regions, became accountable for regional development, but contrary to the European tradition, with only indirect democratic control (Sotarauta 2010). These reorganizations, along with decreasing the number of counties radically in the 1990s, generated a sea change in regional imaginaries. Although the regional media, public services and district organizations, for example, had claimed a provincial presence, Heinonen (1999, see also Paasi 2013) argues that Päijät-Häme started making sense only after the constitution of Regional Councils and the strategic instrumentalization of provinces. Jouni Häkli (1998: 340) argues that state discourses have historically 'colonized' provinces and presented them in a 'universal mould', especially as basic services, spatial imaginaries and performances in everyday life are often anchored in the more pervasive municipalities. The transformations of Päijät-Häme region thus highlight the general problems associated with constructing a sense of territorial permanence and unifying cultural emblems when traces of various regional visions and differentiated but also intermixed cultural practices linger. If we accept that a territory is tightly related to its boundaries, the continuous re-delineation of a region makes it difficult to construct enduring identity discourses and does not allow a regional identity to settle as a vernacular construct (Sagan 2004; Johnson \& Coleman 2012).

\section{Navigating the region, facilitating regional identities: views of regional actors}

Building a region is a political endeavour (Brenner 2004). While the interviewed regional actors produced well-rehearsed characterizations of PäijätHäme, some of which seem to have rotated for decades (cf. Kuikka 1985), the leadership that navigates the province does not always use the same charts.

\section{Territorial imaginaries}

The territorial imaginaries may take their reference from different temporalities and conventions. While the representatives of Päijät-Häme often draw on the historical corpus of the once extensive Hollola, the province sits on the imagined cultural faultline of the Finnish ethos, influenced by Eastern and Western traditions and practices. Most regional actors shared the view that Päijät-Häme appears as a divided part of a historical, picturesque Häme. Whereas one participant 'lives' in Häme, another urgently refutes its existence. The nineteenth century provincial descriptions are still used as social categorizations and conventions in that 'damn, people are different' (Regional education actor 3). The belief in a Hämean identity is obvious in comments that prefer the Hämean lynx symbol over the Päijät-Hämean water nymph, the Hämean Anthem over the Land of the Green Eskers and in the reluctance to define new PäijätHämean values or a 'thin' identity. The regional actors understand that people are proud of their municipalities, coat of arms, parish villages and the traditions in them and of the almost mythical stories of gaining self-administration from Hollola. Former county lines still exist in regional imaginaries, as the quasi-region East-Häme in the northeast and Orimattila in the south are regarded as distinct from the rest (see Fig. 1).

'So the identity is a bit lost in contrast with Savoanness, Karelianness, Ostrobothnianness and so forth. It does not clearly exist. [...] There must be certain foundations, but this is not the heart of Häme and as mentioned, this province is also formed out of Savoan and Uusimaa's municipalities.' (Regional trade actor 1)

While Päijät-Häme is culturally splintered in many ways, quite paradoxically its porousness and growth have given it its coherence. The construction of the province would not have been possible without the population and vigour boost or the pulses, first, from the settlement of Karelians, and second from migration, mainly from Eastern Finland in the 1960s, that gave the city of Lahti impetus to be the economic regional centre and depart from the traditional state administrative city, Hämeenlinna. The result is a primal Hollolan ambience mixed with Eastern Finnish influence that represents itself with what one educational respondent viewed as 'distinct regional methods and ways' (cf. Kallio et al. 2010: 310), with supposed ability to receive and be tolerant. Regardless of the 


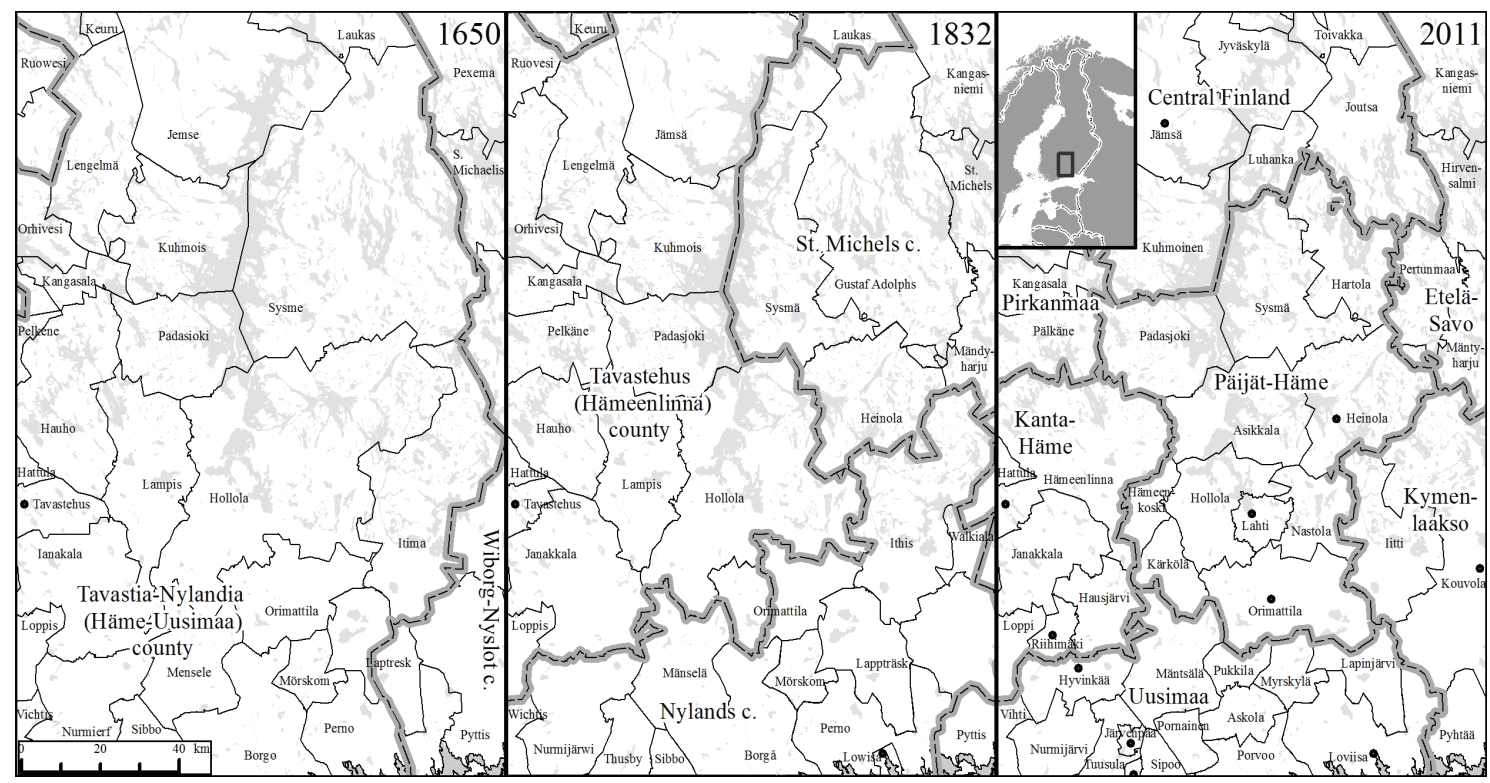

Fig. 1. The case region in 2011 and the county and parish names and boundaries as they were in 1650 and 1832 .

splintered internal nature, no region is an island, although they are sometimes presented as such. In recent years, some more open discourses have emphasized the city-region's connection with the Helsinki Metropolitan Region as a way of deprovincializing the territoriality of Päijät-Häme. In many respects, the geographical proximity to Helsinki leaves it in the shadow in terms of the scarcity of institutional and governmental structures. The co-operative tapping into the capital region is one way to compensate for the boundaries that some feel are incorrectly drawn.

\section{Facilitating regional identities}

There are diverse ways to give the province cultural content and meaning. Previously, Provincial Federations among other associations concentrated on identity building and creating provincial discourses, but in the 1990s, when provinces became responsible for regional development, the work around EU programmes redirected the work of Regional Councils so that traditional identity building and cultivating was left in the background for the sake of outward marketing. One of these marketing campaigns employs the coat of arms of the province and its Vellamo water nymph figure. As a consequence, the local people at least now know what it stands for but it remains highly unrecognis- able outside the province. A collective regional identity cannot be modified or retrofied from a brand. It takes time to transform an entrenched collective identity in the wider public (Sagan 2004). According to the more critical voices, the current discourse of regional development starts from attracting companies and new affluent residents, often by simply emphasizing connections to Helsinki. Inclusive policies and considerations of what actually makes people happy are submitted to the politically-orien(ta)ted competitiveness rhetoric and enterprise originating policies (cf. Bristow 2010: 133-134).

'This is a long, risky and overly complicated sequence to achieve the point that people would start to take an interest in collective issues and to feel some provincial spirit.' (Regional policy actor 3)

Since regions are constantly 'becoming' (Paasi 1986: 137), a successful region-building should be understood as an incessant and unending process, which optimally fuels itself. There is a belief that the terminological Päijät-Hämeanness comes about with the recognition of regional institutions, but the Regional Council, for example, can be seen as a provider of fluent regional collaboration and not that much of an intentional constructor of cultural 'thick' identity. This is in line with the observation of Sotarauta (2010) that regional devel- 
opers do not have ordering power, but rather a 'seductive' one to open up new policies and strategies. There have been attempts to attach content to regional identity discourses, market province-related products, unpack what Päijät-Häme stands for and to frame its meaning through reports and presentations. Nevertheless, their credence is downplayed in some policy circles after one such written attempt 'failed miserably' (Regional education actor 1) and because of the bittersweet remainder of the 'Business City' slogan of Lahti in the 1980s. The respondents felt such attempts should be sufficiently audacious for people to believe that the economy will follow if there is a strong sense of pride for the regional way of doing things (Lanigan 2001). This view is perhaps rather oxymoronic, as the stereotypical, and at certain level, a performed trait of the citizens of the old Häme to this day (cf. Topelius 1879: 168) seems to be modesty and understating their own efforts, even to the point of self-stigmatizing the region as unidentifiable. This discourse of a dismissive character is a form of 'formulaic truth' (Giddens 1994: 63-64) and it has its 'guardians' as long as people believe in and intuitively perform such a discourse.

'One of our identity features is the certain moderation and austerity, that 'let's not make a show of this' $[\ldots]$, which prevents the kind of strong 'we'spirit blustering that exists in some other regions' (Regional trade actor 3)

One reason why the Hämean identity is persistent is the reluctance of the regional media to use the provincial vocabulary. Regional imaginaries break into everyday lives through the regional media. Following them spatially socializes their readers (Hujanen 2000). One regional policy actor maintained that the 'world just seems different when it is read from other newspapers'. The coverage of two main papers Etelä-Suomen Sanomat and Itä-Häme, established in 1914 and 1927, respectively, perpetuate the old county boundaries. According to the majority of the respondents, their style and policy have been rather critical of the idea of and the efforts to create Päijät-Häme without the similar encouraging sentiments for the regional co-operation that exists in some other provinces.

\section{Between thick and thin}

There are two influential discourses that organize the way in which identity, as a form of symbolic power, is conceptualized. These are related to professional positions among various interest groups but also to personal preferences (cf. Paasi 2013). For some participants it is trust in the region's own strengths, traditions, longing, the belief in cultural reconciliation around the province and the reliance on regional spearheads in music, sport and cultural events on which regional cultural consciousness is based. It is sometimes viewed rather elusively as a festive, fleeting spectacle manifesting itself on limited occasions. For others, regional identity is more a matter of relative competitiveness, achievements compared with others and making one's own, regionally labelled formats of success. Both the 'cultural strength' and 'relative competitiveness' readings as internal and external identity strategies are important. The latter, however, is more pervasive and attractive to implement as a policy (cf. Terlouw 2012). For some regional actors, revitalizing regional identity discourses is not really 'a question of investments and contributions' or agreeing on the territorial terminology.

'Rather they are questions of passion. And these identity issues are in the end the sorts of mysteries like love. That when people feel comfortable, they commit to and work for the benefit of a wider society. That is identity building.' (Regional media 1)

Moreover, the interviews indicate that the traditional collective identity discourse or 'thick' identity (Geertz 1973; Terlouw 2012) is by no means eroding, even if it is considered 'light', but it is shielded under the competitiveness discourse in which regional actors feel obliged to take part. The regional actors maintain that people start to act on behalf of their environment but this does not operate in the name of Päijät-Häme, rather on the local society. Throughout the interviews, the respondents seem to highlight their organization's 'working territory', Häme, Päijät-Häme, East-Häme or Lahti Region, which appears to them as a natural occupational and institutional entity, and understand that provincial consciousness and symbols can be a side issue for the citizens of the province.

The porousness of the region can lead to viewing Päijät-Häme as a fabricated setting with territorial identity claims made first to the municipalities partitioned from mediaeval Hollola. Some even disclose the readiness to downplay the idea of the province, as it will never become an important source of identity like the historical provinces, and go on to state that 'Päijät-Hämeanness could appear as a sort of province that breaks into the future and a statement of a new kind of identity' (Re- 
gional media 1) that relies on its functional position in relation to the metropolitan region.

\section{Narrative claims to the region: social movement views}

Päijät-Häme offers a framework to exemplify how slowly personal identities transform to correspond with both transformed regional constellations and new, entitled identity repertoires. In some cases, new spatial identities are never adopted or identities continue to follow life-paths and trajectories originated elsewhere (Anderson 2010: 120; Vainikka 2012).

\section{The importance of local history}

The involved social movement members from the locally- to the universally-orientated groups reported that the province has remained rather nebulous and distant, despite the fact that participants were surprisingly conscious of regional history. ${ }^{6}$ They were aware of the splintered character of the province and the ostensible cohesion between certain municipalities based on old congregate and parish allegiances ${ }^{7}$ within and over the current regional boundaries. Participants in Lahti and Hollola repeated the well-trodden historical understanding of long-established settlement and Hollola as a heartland, with its influence reaching the wilderness far to the north. Respondents in the northern part of the province regarded their municipality as an innate stronghold and agreed on an informal region of East-Häme extending to two other regions, replicating the mediaeval parish of Sysmäki, left as a sort of outcast between the old county and the new regional boundary (see Fig. 1). The following excerpt from a focus group session with a Local Heritage Association in Sysmä is likely to be similar to the collective understandings expressed in Hollola.

'This was the focal parish, or this was the hub and it spread out from here, so that this was the biggest population centre of Lake Päijänne a thousand years ago.' (Matti, 55)

'Sysmä extended all the way up to Rautalampi and Pertunmaa.' (Kai, 61)

'Behold, you know the same blather.' (Olavi, 62)
In contrast, the 107-year-old central city, Lahti, is regarded throughout the focus groups as 'young and impersonal', 'hulking', 'a place that leaves one cold' or 'a city of the migratory'. The province then is regarded as a mix of inherited, fading parish dignity and novel, rootless city-regionalism - a palimpsest space where the residues of former regional constructs meet the contemporary development discourses (cf. Riikonen 1995; Schein 1997; Vainikka 2012). There are positive sentiments towards the city, of its closeness to nature, early modernization, proximity to Helsinki and its image in terms of sport and classical music, but the city itself exemplifies the anxiety that is related to the detachment of and breaches in longer lineages, as Viipurian and Karelian ${ }^{9}$ contexts and Hämean foundations have intermixed. Ritva, 63, an Amnesty member lamented that 'there are so many people who themselves do not know where they come from', whose loose spatial identity influences their well-being. While it may seem that 'throwntogetherness' creates new forms of spatial identities (Massey 2005: 151), it does not necessarily provide an anchor for individuals, and this is certainly true for the resettled Karelians longing for and missing their 'spiritual connections' with their ancestral homes (Hyytiäinen 2005, see also Böök 2004: 40).

\section{Conceptualizing identity}

The social movement respondents defined identity as the core of consciousness pearled by one's cultural roots, life paths and values in a community, as a longitudinal understanding of being a child of one's epoch and as courage to individualize oneself using a 'bricolage' of memberships or 'a narrative of what is at hand' (Leyshon \& Bull 2011: 163). Apart from this 'layered socialization', they agreed that identity is also founded on common labels and the ways society regards various groups (Tajfel 1981). Identity stands as both an expression of internal sentiments and an attachment to external icons whereupon the process of self-understanding of one's positionality in a social, cultural and material setting constantly reproduces itself. With all the relational examples of identities becoming multiple and more mobile (Massey 2005), there seems to be a pronounced kernel of continuity and materiality, even with the more universallyorientated participants, which does not always chime with the administrative spaces. 
Based on this diverse reading on how space may influence identity, most respondents presented a dual place identity or spatial attachments that are bound to multiple locales and are activated when talking about them (cf. Savage et al. 2005). Multiple sources of identity are linked to family roots, historical layers, urban or rural landscapes, meaningful places or localities of studying or working life. Put another way, places continuously mould our self-understanding and the experiences of them sediment over each other.

\section{Relating to Päijät-Häme}

It is difficult to disentangle the role of the province within the spectrum of spatial identity. One Amnesty respondent argued that Päijät-Häme is too extensive, stating that:

'When you think of it, on a personal level, isn't the area so extensive that you don't feel it your own? It is the neighbourhood where you can travel by bicycle, on foot or by canoe that is your region.' (Ritva, 63)

The spatial attachment of this participant could be understood as a form of personal, corporeal reach or the physical ability to access different landscapes. At the same time, it highlights that the term 'Päijät-Häme' is not an established identity factor in everyday life and it is not included in the narrative of one's self. According to the social movement participants, the city of Lahti determines the character of the province so much that it urges people to ask, 'What would be PäijätHämeän?' (Pauliina, 25, Youth Society). The term is not extensively used and it functions as an obscure concept. Nevertheless, the participants had recognized the persistent region-building projects and seen brochures, in which as a Youth Society member Petri, 32, ironically put it 'The visibility of the ski jumps in every picture seems to be the most important thing'. In the same discussion, Johannes, 71 maintained that it became important to mix city-regionalism with the ghosts of provinciality and form a partial Häme for functional reasons. He continued that the region-building as a social and cultural endeavour 'has not really succeeded. Such a region's own identity has not developed here'. Politically, functional regionalism has only created a 'deep ditch' within the Häme electoral district. The current cultural-linguistic landscape of the province is even presented simply as 'void' and this situated understanding of not really having a dialect of its own dampens the claims made to a coherent regional identity (Jones \& Fowler 2007). Awareness of the historical provinces is well-established as a cultural substrate or as tribal clichés ordering social categories, but the contemporary 'partial' provinces do not have an equivalent status. Even though the respondents notice cultural differences between Finnish regions, they suggest that the contemporary provinces are not that important in everyday life and do not appear as conventions to structure the country. The historical regions, old counties and cardinal directions constitute the core of the vocabulary which people use to make sense of spatial variations within the country (cf. Antonsich 2010).

\section{Reading regional symbolism}

The iconography and the symbolic power of Päijät-Häme are also contested. The coat of arms for the province was introduced in 1997, when a noted graphic designer redrew one of Jac. Ahrenberg's early twentieth century designs for the coat of arms for Lahti. At the time, the romanticism-inspired design was considered too daring and the city selected a more conventional railway wheel for their emblem. When the time came to select a new regional emblem, the Vellamo water nymph figure consolidated with a Karelian-associated cuckoo bird represented continuity that other choices did not. ${ }^{10} \mathrm{~A}$ picture of the coat of arms inspired two kinds of sentiments. Some of the respondents saw it as a delicate and positive image. For a Local Heritage Association member, Erkki, 67 , for instance, it represented 'calm and comely future' with a Kalevalan mythical spirit. Overall, the regional actors were more enthusiastic about the symbol. One policy actor even thought that it is the 'most emotional and successful among Finnish regions'. The response in the focus groups to the emblem was mainly negative; one respondent actually turned the picture upside down after I handed them a copy of it and she thought it was appalling. When the emblem is not understood as part of the imagery of the national epic or antiquity, it appears untrustworthy, distant and a mockery of the city's design repute. A Youth Society participant explains how the Hollo and Martta giants that a myth places as the constructors of the Hollola church gained appreciation but the newly introduced emblem did not.

'Päijät-Häme was featured in Senate Square and we also performed there with Hollo and Martta giants with us and the show gained enormous ap- 
preciation from the audience and then we had fantasy girls of this kind and I felt like such a stranger so that this is ... the whole picture is so distant.' (Antero, 54)

The idea of accessible and inherited municipalities is the ordering concept of spatiality, especially among the Local Heritage and Youth Society participants. Even when boundaries are maintained to be artificial, the opposition to restructuring the municipal structure is evident in every group. This is a significant issue as a large enough municipal merger, of which there were unsuccessful plans in 2010, might make the Regional Council, the backbone of the province, redundant. The historically emerged 'civil society regionalism' and economic political 'functional regionalism' (Jones 2004) are both highly visible, while not always in the name of the province. A Local Heritage group participant, Jouko, 61, maintained, 'If we preserved old emblems and old names, things would be a lot simpler. Administration may be whatever it happens to be'. Thus, political territoriality may be left as a bystander when the regional symbols or practices become more important. The realization of empathy towards symbolic regionalism separates the locally- and more universally-orientated groups. A Friends of the Earth member, Marko, 32, however, evoked an ideal community and wished that 'managing shared issues could be more than party politics'.

\section{Regional identity and globalization}

Regional identity cannot be understood fully without considering the extent of people's life-worlds and globalization. In the interviews, globalization manifests itself as a technological change that enables both the omnipotent encroachment of homogenizing culture and the branching of cultural literacy. For the Friends of the Earth and Amnesty participants, regionalism is not an answer to more pressing global problems. However, across the interview material, participants were uneasy about the perceived lack of interest in the people's own local culture and the lack of knowledge of the kind that is just around the corner' (Marko, 32, Friends of the Earth). The members of the Youth Society were particularly anxious about being kneedeep in pop-culture at the expense of consciousness about one's own local cultural traditions.

Globalization has helped to understand regional identities as social constructs, 'mentifacts' and to recognize their relational qualities in that in the end we here and they over there are the same' (Ritva, 63, Amnesty). Regions are always generated through narratives and performable practices, but there is an apparent paradox in mass communication-influenced national identification. The participants argued that people believe in the national imagined community (Anderson 1983) but 'know their own country rather poorly' (Marjatta, 63, Amnesty). They suggested that at times this leads to forgetting one's own identity or strained categorizations where, as implied by a Youth Society member Johannes, 71, 'people have to be pigeon-holed as Hämeans and Ostrobothnians as regional awareness is not that conclusive'. While a plethora of issues from welfare-malaise to inequality and from the cultural disorientation to economic myopia worries the participants, the issue of breakage of society and families is the most disquieting. Although the modern world might seem more stretched and comprised of what Bauman (2004: 69) might call 'thin and shallow contacts' this does not appear to be what people actually want.

\section{Discussion}

Regional identity has become a buzzword in some strands of political, urban and cultural geography and in regional development practice. Yet the dominating instrumental views of governance, competitiveness ideology and place marketing do not often find an affective counterpart in civil society (Antonsich 2010: 273, also Boisen et al. 2011; Häkli 1998). This case study suggests that there are multiple reasons for this cleavage. First, the idea of palimpsest, applicable to basically every region, addresses the need to understand the institutionalization of regions (Paasi 1986) as an asynchronous process where different socio-spatial practices and discourses are simultaneously used in everyday life and in media but also in the sometimes closed circuits of professionally positioned regional actors. In the case of Päijät-Häme, space and landscape are undoubtedly sources of individual and collective identities for the citizens and regional actors alike. Yet the competing longitudinal regional discourses can create a sense of uncertainty, leave the region splintered and produce friction in the creation and adoption of new regional frames. This is not unique to Finland, where governors and governments have redrawn administrative spaces. Contemporary Europe, for exam- 
ple, is scored with relics of old boundaries (Keating 1998). According to the respondents interviewed in this study, regionalism that is based on historical layers should not be forgotten in contemporary developing-by-competition practices. The relative prestige, however, cannot be an achievement by itself and should not become a burden to development (cf. Jones \& MacLeod 2004), especially as the province is so closely tied to the development of the city-region.

Second, it seems that the political emphasis on regions (Keating 2001) precedes both the imaginaries of the citizens and the regional actors. While the focus groups revealed a low level of attachment to the province and ignorance of the provincial concept, the regional actors were rather realistic - some even cynical - about the attraction of the provincial rhetoric. Their professional position and acting in multiple functional co-operation networks enforce an image that regions have a voice and that they manifest as near-essential entities, but the various terminologies and spatial configurations of different stakeholders and the idea of a metropolitan node leave a plethora of territorial and relational practices in their wake. This emphasizes the need to understand the region as both porous and bounded (Morgan 2007). The lack of direct political participation and the reluctance of the main guardian of regional discourses - the regional press - to routinely frame Päijät-Häme, leaves the region as a discursively nebulous notion. However, the continuous denial of regional identity as a 'formulaic truth' is a form of regional identity in itself. Even though the sense of community does not manifest into a definitive symbolic level, it might be more disastrous to rearrange the region and dissipate the region-building work done so far. Especially since some regional actors interpret the general depreciation of the region as an act of belonging.

Third, reformulating content for regional identity narratives, and regions in more general, is a form of practicing authority over collective spatial vocabularies. It requires considerable legitimacy to make such vocabularies effective in regional development work. An important question was asked by one regional policy actor. 'How is regional development possible if there is no audience or people that want to take part in the region?' If the region does not share a common acceptance and recognition among its citizens, regional development projects can be hard to justify, as labelling people according to territorial divides is not the same as claiming the territory as an identity factor. Weak recognition can turn regions into a yet another way of securing and funnelling development funds without locally engaging, advocating work (cf. Paasi 2002b: 138). According to the regional actors in Päijät-Häme, identity and regional culture are relatively important and should be the starting point of regional policies, or at least be a source of passion reflected in the development of the region. Often these discourses do not permeate to everyday language. Instead, the now commonplace relational conceptualizations of regions that tap into more affluent regions presage more uneven development (Bristow 2010: 123, also Moisio 2007).

Finally, this study shows that among citizens it is easier to find identifications and attachments to a place in a sense of 'layered' internal sentiments than a collective loyalty to regions in a sense of attachments to external icons (Vainikka 2012). This could be interpreted as a sign of growing individualism, but collective belonging has not disappeared. The results indicate that it is not justifiable to take regional identity only as a form of political rhetoric and to believe that globalization and individualization have killed off regional collective identities (cf. Terlouw 2012). On the contrary, owing to regional changes, whether by one's own mobility or regional transformations, the interviews show that individuals can feel lost with their unaccounted longing for somewhere. Thus, there is a clear space for region-building and branding that would resonate with the citizens and their everyday life. The content and audience for it, however, must be designed to be compatible with the existing spatial imaginaries and ideals of the citizens already living in the region. Going back to the quotation by Henri Bergson at the beginning,

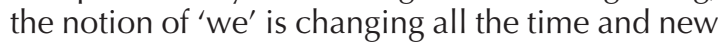
meanings are merged into it but this change is also enmeshed in the localized spatial knowledge that unceasingly reworks the past to understand the present.

Thus, as a wider implication, regional identity cannot be a label given to regions by their marketers, but a continuous process involving both the regional actors who create and sustain the understandings of a region and every citizen of the region who read the geohistorical formation of the region and perform the current discourse. Taking for granted regional identity based on imperative checklists can be a treacherous practice, as identity is more often a bricolage of sentiments, 
thoughts and practices, some of which are shared but which are in due course remoulded (Leyshon \& Bull 2011). In the end, if we want to analyze regional identities, we should ask the people themselves.

\section{NOTES}

${ }^{1}$ On conceptualizing 'thick' and 'thin' see for example Geertz (1973) and Sack (1997: 257).

${ }^{2}$ The regional actors included representatives from the following institutions: The Regional Council of Päijät-Häme (2), the Employment and Economic Development Centre for Häme, Lahti Regional Development Company, Entrepreneurs of Päijät-Häme, Häme Chamber of Commerce, Lahti Region Education Consortium, Lahti University of Applied Sciences, Lahti City Museum, Etelä-Suomen Sanomat and Itä-Häme. The EED Centre and the Chamber of Commerce also cover the province of Kanta-Häme.

${ }^{3}$ The material dates to the time before the government-led discussion of strong and dynamic municipalities and, though municipal mergers were an issue at the time of the interviews, it provides an invaluable insight into regional identity without it being 'activated' by governmental discourse.

${ }^{4}$ The official administrative parlance for the most part started to use the word 'region' for maakunta when Regional Councils were created. The term 'province' is used here as an analytical concept (cf. Häkli 1998), not as a positioned style that commonly denotes 'provinces' as non-metropolitan territories.

${ }^{5}$ Swedish was the official language until 1863, and the paper uses the contemporary Swedish administrative names up to that point.

${ }^{6}$ The respondents regarded that, for example, Lammi and Hämeenkoski, Sysmä, Hartola and Pertunmaa, Hollola and Kärkölä have more in common with each other than with the rest of the region. Similarly, littianness, based on a sixteenth century parish, is regarded as a 'concept' in itself.

7 There were subtle differences in the ways the participants scaled their spatial identities. The members of the Youth Society and especially the Local Heritage Association felt that they were attached slightly more to local spaces, whereas the members of the Friends of the Earth and Amnesty had more pronounced attachments to macro-regional constructs such as Europe and the Nordic Countries.

${ }^{8}$ All names are pseudonyms.

${ }^{9}$ As a telling anecdote, one participant recalled that mainly resettled Karelians organized the five-hun- dred-year anniversary celebration of the Hollola church. The ostentatious and at first Catholic stone church was built next to an ancient Kapatuosia hillfort, a derivative of Cappadocia that is more important to 'Eastern' cultures.

${ }^{10}$ Even though the Vellamo figure is applied, for example, to a children's book and to the side of mineral water bottle, the mermaid does not carry the same kind of symbolic meaning as, for example, Syrenka in the Warsaw coat of arms. See http://www. paijathame.fi/en.

\section{ACKNOWLEDGEMENTS}

The author would like to thank the two anonymous reviewers for their valuable comments and Anssi Paasi and Kaj Zimmerbauer for their advice. Writing this article was made possible by funding provided through an Academy of Finland project (Grant number \#121992).

\section{REFERENCES}

Agnew J 2001. Regions in revolt. Progress in Human Geography 25: 1, 103-110. http://dx.doi.org/10.1 191\%2F030913201673210318.

Allen J, Massey D \& Cochrane A 1998. Rethinking the region. Routledge, London.

Anderson B 1983. Imagined communities. Verso, London.

Anderson J 2010. Understanding cultural geography. Routledge, London.

Antonsich M 2010. Exploring the correspondence between regional forms of governance and regional identity: the case of Western Europe. European Urban and Regional Studies 17: 3, 261-276. http://dx.doi.org/10.1177\%2F0969776410365784

Barbour RS 2005. Making sense of focus groups. Medical Education 39: 7, 742-750. http://dx.doi. org/10.1111\%2Fj.1365-2929.2005.02200.x

Bauman Z 2004. Identity. Polity, Cambridge.

Bergson H 1911. Creative evolution. H. Holt and Company, New York.

Bialasiewicz L 2002. Upper Silesia: rebirth of a regional identity in Poland. Regional and Federal Studies 12: 2, 111-132. http://dx.doi.org/10.1080\%2F714004749.

Boisen M, Terlouw K \& van Gorp B 2011. The selective nature of place branding and the layering of spatial identities. Journal of Place Management and Development 4: 2, 135-147. http://dx.doi.org /10.1108\%2F17538331111153151.

Bosco FJ \& Herman T 2007. Focus groups as collaborative research performances. In DeLyser D, Herbert S, Aitken S, Crang M \& McDowell L (eds). 
The SAGE Handbook of Qualitative Geography, 193-207. SAGE, London.

Brenner N 2004. New state spaces. Oxford University Press, Oxford.

Bristow G 2010. Critical reflections on regional competitiveness. Routledge, London.

Böök N 2004. Border Karelia through rose-coloured glasses? Gazes upon a ceded territory. Fennia 182: $1,33-45$.

Cooke P \& Morgan K 1999. The associational economy. Oxford University Press, Oxford.

de Cillia R, Reisigl M \& Wodak R 1999. The discursive construction of national identities. Discourse \& Society 10: 2, 149-173. http://dx.doi.org/10.11 77\%2F0957926599010002002.

Deacon B 2004. Under construction: culture and regional formation in South-West England. European Urban and Regional Studies 11: 3, 213-225. http://dx.doi.org/10.1177\%2F0969776404044018.

Donaldson A 2006. Performing regions: territorial development and cultural politics in a Europe of the Regions. Environment and Planning $A$ 38: 11, 2075-2092.http://dx.doi.org/10.1068\%2Fa37104.

Florida R 1995. Towards the learning region. Futures 27:5,527-536.http://dx.doi.org/10.1016\%2F0016$3287 \% 2895 \% 2900021-\mathrm{N}$.

Frisvoll S \& Rye JF 2009. Elite discourses of regional identity in a new regionalism development scheme: the case of the 'Mountain Region' in Norway. Norsk Geografisk Tidsskrift 63: 3, 175-190.http:// dx.doi.org/10.1080\%2F00291950903238990.

Geertz C 1973. The interpretation of cultures. Basic Books, New York.

Giddens A 1994. Living in a post-traditional society. In Beck U, Giddens A \& Lash S (eds). Reflexive modernization, 56-109. Polity Press, London.

Gustafson P 2001. Meanings of place: everyday experience and theoretical conceptualizations. Journal of Environmental Psychology 21: 1, 5-16. http://dx.doi.org/10.1006\%2Fjevp.2000.0185.

Heinonen J 1997. Päijät-Häme I. Päijät-Hämeen Liitto \& Lahden Kaupunki, Lahti.

Heinonen J 1999. Päijät-Häme III. Päijät-Hämeen Liitto \& Lahden Kaupunki, Lahti.

Hobsbawm E 1983. Introduction: inventing traditions. In Hobsbawm E \& Ranger T (eds). The invention of tradition, 1-14. Cambridge University Press, Cambridge.

Hopkins PE 2007. Thinking critically and creatively about focus groups. Area 39: 4, 528-535. http:// dx.doi.org/10.1111\%2Fj.1475-4762.2007.00766.x.

Hujanen J 2000. Journalismin maakunnallisuus. University of Jyväskylä, Jyväskylä.

Hyytiäinen M 2005. Vaeltavien sielujen paikka. In Huovila M \& Willman T (eds). Karjala Lahdessa, 109-126. Palmenia Kustannus, Lahti.

Häkli J 1998. Discourse in the production of political space: decolonizing the symbolism of provinces in Finland. Political Geography 17: 3, 331-363.

Johnson A 1996. 'It's good to talk': the focus group and the sociological imagination. The Sociologi- cal Review 44: 3, 517-538. http://dx.doi. org/10.1111\%2Fj.1467-954X.1996.tb00435.x.

Johnson C \& Coleman A 2012. The internal other: exploring the dialectical relationship between regional exclusion and the construction of national identity. Annals of the Association of American Geographers 102: 4, 863-880. http://dx.doi.org/1 $0.1080 \% 2 F 00045608.2011 .602934$.

Jonas AEG 2012. Region and place: regionalism in question. Progress in Human Geography 36: 2, 263-272.

http://dx.doi.org/10.1177\%2F0309132510394118.

Jones M 2004. Social justice and the region: grassroots regional movements and the 'English question'. Space and Polity 8: 2, 157-189. http://dx. doi.org/10.1080\%2F1356257042000273940.

Jones M \& MacLeod G 2004. Regional spaces, spaces of regionalism: territory, insurgent politics and the English question. Transactions of the Institute of British Geographers 29: 4, 433-452. http://dx.doi. org/10.1111\%2Fj.0020-2754.2004.00140.x.

Jones R \& Fowler C 2007. Where is Wales? Narrating the territories and borders of the Welsh linguistic nation. Regional Studies 41: 1, 89-101. http:// dx.doi.org/10.1080\%2F00343400600928343.

Jutikkala E 1949. Suomen maakunnat. Kotiseutu 1949: 6-8.

Järvinen O 1968. Maakunnallinen yhdentyminen. Suur-Hollola 1968: 1, 3.

Kallio A, Harmaakorpi V \& Pihkala T 2010. Absorptive capacity and social capital in regional innovation systems: the case of the Lahti region in Finland. Urban Studies 47: 2, 303-319.

http://dx.doi.org/10.1177\%2F0042098009346373.

Keating M 1998. The new regionalism in Western Europe. Edward Elgar, Cheltenham.

Keating M 2001. Rethinking the region. Culture, institutions and economic development in Catalonia and Galicia. European Urban and Regional Studies 8: 3, 217-234. http://dx.doi.org/10.1177\%2F096977640100800304.

Kerkkonen M 1962. Länsimaisen Suomen vanhin raja. Historiallinen Aikakauskirja 1962: 4.

Kuikka J 1985. Päijät-Hämettä vasta-alkajille. PäijätHämeen Seutukaavaliitto A 21.

Lanigan C 2001. Region-building in the North East. In Tomaney J \& Ward $\mathrm{N}$ (eds). A region in transition, 104-119. Ashgate, Aldershot.

Leyshon M \& Bull J 2011. The bricolage of the here: young people's narratives of identity in the countryside. Social \& Cultural Geography 12: 2, 159-180. http://dx.doi.org/10.1080\%2F14649365.2011.545141.

MacLeod G \& Jones M 2001. Renewing the geography of regions. Environment and Planning $D$ 19: 6, 669-695. http://dx.doi.org/10.1068\%2Fd217t.

Massey D 2005. For space. SAGE, London.

Moisio S 2007. Valtiomuutoksen tuottaminen Suomessa: poliittisen maantieteen näkökulma. Politiikka 49: 4, 229-247.

Morgan K 2007. The polycentric state: new spaces of empowerment and engagement? Regional Studies 
41: 9, 1237-1251. http://dx.doi.org/10.1080\% 2F00343400701543363.

Paasi A 1986. The institutionalization of regions: a theoretical framework for understanding the emergence of regions and the constitution of regional identity. Fennia 164: 1, 105-146.

Paasi A 2002a. Place and the region: regional worlds and words. Progress in Human Geography 26: 2, 802-811. http://dx.doi.org/10.1191\%2F0309132 502ph404pr.

Paasi A 2002b. Bounded spaces in the mobile world: deconstructing 'regional identity'. Tijdschrift voor Economische en Sociale Geografie 93: 2, 137-148. http://dx.doi.org/10.1111\%2F1467-9663.00190.

Paasi A 2009a. Regional geography I. In Kitchin R \& Thrift N (eds). International encyclopedia of human geography, 214-227. Elsevier, Amsterdam.

Paasi A 2009b. The resurgence of the 'region' and 'regional identity': theoretical perspectives and empirical observations on regional dynamics in Europe. Review of International Studies 35: S1, 121-146. http://dx.doi.org/10.1017\%2FS0260210509008456.

Paasi A 2013. Regional planning and the mobilization of 'regional identity': from bounded spaces to relational complexity. Regional Studies, in press. http://dx.doi.org/10.1080\%2F00343404.2012.661410.

Petrella R 2000. The future of regions: why the competitiveness imperative should not prevail over solidarity, sustainability and democracy? Geografiska Annaler B 82: 2, 67-72. http://dx.doi.org/10.1111\%2F1468-0467.00074.

Prytherch DL 2010. 'Vertebrating' the region as a networked space of flows: learning from the spatial grammar of Catalanist territoriality. Environment and Planning A 42: 7, 1537-1544. http://dx.doi. org/10.1068\%2Fa42430.

Putnam R 1994. Making democracy work. Princeton University Press, Princeton.

Ricœur P 2000. La Mémoire, I'Histoire, I'Oubli. Seuil, Paris.

Riikonen H 1995. Sukupolvet ja alueellinen muutos. Terra 107: 2, 88-100.

Sack RD 1997. Homo geographicus. The Johns Hopkins University Press, Baltimore.

Sagan I 2004. Looking for the nature of the contemporary region. Progress in Human Geography 28: 2, 141-144. http://dx.doi.org/10.1191\%2F03091 32504ph477xx.

Savage M, Bagnall G \& Longhurst B 2005. Globalization and belonging. SAGE, London.

Sayer A 1989. The 'new' regional geography and problems of narrative. Environment and Planning D 7: 3, 253-276. http://dx.doi.org/10.1068\%2Fd070253.

Schein RH 1997. The place of landscape: a conceptual framework for interpreting an American scene. Annals of the Association of American Geographers 87: 4, 660680. http://dx.doi.org/10.1111\%2F1467-8306.00072.
Schlottmann A 2008. Closed spaces: can't live with them, can't live without them. Environment and Planning D 26: 5, 823-841.

http://dx.doi.org/10.1068\%2Fd0706.

Sotarauta M 2010. Regional development and regional networks: the role of regional development officers in Finland. European Urban and Regional Studies 17: 4, 387-400.

http://dx.doi.org/10.1177\%2F0969776409352581.

Syssner J 2009. Conceptualizations of culture and identity in regional policy. Regional and Federal Studies 19: 3, 437-458.

http://dx.doi.org/10.1080\%2F13597560902957518.

Taavitsainen JP 1990. Ancient hillforts of Finland, problems of analysis chronology and interpretation with special reference to the hillfort of Kuhmoinen. Suomen Muinaismuistoyhdistyksen Aikakauskirja 94.

Tajfel H 1981. Human groups and social categories. Cambridge University Press, Cambridge.

Terlouw K 2012. From thick to thin regional identities? Geolournal 77: 5, 707-721. http://dx.doi.org/10.1007\%2Fs10708-011-9422-x.

Thrift N 1983. On the determination of social action in space and time. Environment and Planning $D 1$ : 1, 23-57. http://dx.doi.org/10.1068\%2Fd010023.

Thrift N 1990. For a new regional geography 1. Progress in Human Geography 14: 2, 272-279. http:// dx.doi.org/10.1177\%2F030913259001400205.

Tomaney J 2007. Keeping a beat in the dark: narratives of regional identity in Basil Bunting's Briggflatts. Environment and Planning D 25: 2, 355375. http://dx.doi.org/10.1068\%2Fd411t.

Topelius Z 1879. Boken om Wårt Land. 3rd ed. G.W. Edlund, Helsingfors.

Tuffin K \& Howard C 2001. Demystifying discourse analysis. In McHoul A \& Rapley M (eds). How to analyse talk in institutional settings, 196-205. Continuum, London.

Vainikka J 2012. Narrative claims on regions: prospecting for spatial identities among social movements in Finland. Social \& Cultural Geography 13: 6, 587-605. http://dx.doi.org/10.1080\%2F14649365.2012.710912.

van Houtum H \& Lagendijk A 2001. Contextualising regional identity and imagination in the construction of polycentric urban regions: the cases of the Ruhr area and the Basque country. Urban Studies 38: 4, 747-767. http://dx.doi.org/10.1080\%2F00420980120035321.

Warren CAB \& Karner TX 2010. Discovering qualitative methods. Oxford University Press, Oxford.

Werlen B 2009. Regionalisations, everyday. In Kitchin R \& Thrift N (eds). International encyclopedia of human geography, 286-293. Elsevier, Amsterdam.

Zimmerbauer K 2011. From image to identity: building regions by place promotion. European Planning Studies 19: 2, 243-260. http://dx.doi.org/10. 1080\%2F09654313.2011.532667. 